\title{
Concentrations and Mass Fluxes of Chloroacetic Acids and Trifluoroacetic Acid in Rain and Natural Waters in Switzerland
}

\author{
Michael Berg*, Stephan R. Müller, Jürg Mühlemann, Adrian Wiedmer, \\ and René P. Schwarzenbach
}

Revised Manuscript ES 990855F ( $2^{\text {nd }}$ Revision)

April 2000

Swiss Federal Institute for Environmental Science and Technology (EAWAG), and Swiss Federal Institute of Technology (ETH), CH-8600 Dübendorf

${ }^{*}$ Corresponding author. Phone: +41-1-823 50 78; Fax: +41-1-823 5028

E-mail: michael.berg@eawag.ch

This document is the Accepted Manuscript version of a Published Work that appeared in final form in Environmental Science and Technology, copyright @ American Chemical Society after peer review and technical editing by the publisher. To access the final edited and published work see http://doi.org/10.1021/es990855f. 


\section{Abstract}

Chloroacetic acids (CAAs) and trifluoroacetic acid (TFA) are widely distributed environmental pollutants. The origin of CAAs is still under debate, while TFA is considered to be a major atmospheric degradation product of recently introduced hydrochlorofluorocarbons (HCFCs) and hydrofluorocarbons (HFCs). Because of the phytotoxic potential of the CAAs, i.e., monochloroacetic acid (MCA), dichloroacetic acid (DCA) and trichloroacetic acid (TCA) and the persistence of TFA, these compounds are of considerable environmental concern. Hence, it is important to know their fluxes and their spatial and temporal distribution in the environment. In this study, the occurrence and mass fluxes of MCA, DCA, TCA, and TFA were assessed on a regional scale over Switzerland, based on more than 1000 concentration measurements in rain and snow, surface water, ground water, and waste water. Among different precipitation events, the measured concentrations varied significantly from $<11 \mathrm{ng} / \mathrm{L}$ to $7100 \mathrm{ng} / \mathrm{L}$. However, no statistically different average haloacetic acid (HAA) concentrations among six precipitation sampling sites located in various areas in Switzerland were observed (range of average concentrations: MCA 1430-2770 ng/L, DCA 390-1370 ng/L, TCA 95-380 ng/L, TFA 33-220 ng/L). The similar average HAA concentrations in precipitation at a remote site close to the free troposphere at an elevation of $3580 \mathrm{~m}$ above sea level (Jungfraujoch) and at a site which receives precipitation which scavenged the Earth's boundary layer (urban site Dübendorf/Zürich) suggests that HAAs are derived from well mixed precursor(s) in the atmosphere. When moving from precipitation to surface waters (i.e. rivers), the TFA/CAA ratios increased by a factor of 10-11 for TFA/MCA and TFA/DCA, and by a factor of 1.2 for TFA/TCA. Mass flux calculations show, that precipitation is the dominant source of the HAAs, particularly of MCA, DCA and TFA (>95\%). In the case of TCA waste water effluents contributed $27 \%$ of the total input. The results indicate that compared to the CAAs, TFA is quite persistent in the aquatic and terrestrial environment, and may thus accumulate in soils and ground water. 


\section{Introduction}

Halogenated acetic acids (HAAs), i.e., monochloroacetic acid (MCA), dichloroacetic acid (DCA), trichloroacetic acid (TCA), and trifluoroacetic acid (TFA) are of considerable concern because of their wide-spread occurrence in the environment (1-9). Chloroacetic acids (CAAs) are plant growth inhibitors $(1,10)$. In fact, TCA and MCA were used as herbicides until the late 1980s. Trifluoroacetic acid is considered to be less phytotoxic than the CAAs (11), however, it is more persistent, and might lead to long-term contamination in certain terrestrial ecosystems $(12,13)$.

The major sources of the chloroacetic acids which are currently under debate include: i) formation in the atmosphere by photochemical degradation of chlorinated solvents $(1,2,14)$, and ii) compounds that occur naturally (15). Further, formation of HAAs during water treatment by the reaction of chlorine containing agents with organic matter during bleaching and disinfecting processes (e.g., swimming pool water (2), drinking water (16)) has been shown to be another potential source (2). However, the relative importance of these sources and the proposed mechanisms of formation in the atmosphere are still not very well known. In contrast to the uncertainty in case of the CAAs, it is commonly believed that the major source of TFA is the atmospheric degradation of some of the increasingly used hydrochlorofluorocarbons HCFC-123 (CHCl2-CF3), HCFC-124 (CHClF-CF3) and mainly of the hydrofluorocarbon HFC-134a (CHF2-CF3) $(17,18)$. Nevertheless, recent studies suggest that TFA could partly originate from other, yet unknown sources $(4,8)$.

An important input pathway of HAAs into the biosphere is washout by rain from the atmosphere $(2,3,19)$. In soils and aquifers, HAAs (pKa $0.3-2.9)$ are very mobile $(20,21)$. For the CAAs abiotic and microbial degradation are considered to be important elimination pathways (22,23). In contrast, TFA seems to be persistent in water, soil and sediments $(12,19,20)$. Visscher et al. (24) reported microbial degradation of TFA in a lake and saltmarsh sediment under oxic and anoxic conditions, however the results could not be confirmed by Emptage and coworkers (25). 
Despite various reports on the occurrence of haloacetic acids in the environment have been published, there is still a lack of more comprehensive studies that provide a data base for the quantification of mass fluxes on a larger scale. In the study described in this paper, the occurrence, the fate, and the mass fluxes of MCA, DCA, TCA and TFA have been assessed simultaneously in the aquatic environment in Switzerland which covers an area of 41,000 $\mathrm{km}^{2}$. The very divers topography of Switzerland (see Figure 1 and Table 1) represents an ideal location to investigate both local point sources and diffuse input routes of haloacetic acids. Within a well defined area, one is able to compare concentrations of the target compounds in precipitation at alpine sites situated close to the free troposphere (e.g., Jungfraujoch, $3580 \mathrm{~m}$ above sea level) with those determined in highly populated sites located in the Swiss Midland (e.g., Dübendorf, a suburb of Zürich, $430 \mathrm{~m}$ above sea level), where pollutants are scavenged by rain from the Earth's boundary layer. Furthermore, Switzerland comprises rural and industrial areas, pristine mountain lakes and lakes of the Swiss Midland that vary in size and hydrology, moors, and a variety of rivers differing in size and anthropogenic load. Finally, and most importantly, there is no major input of water except by precipitation, and the export of water occurs predominantly $(>90 \%)$ by the two rivers Rhine and Rhone. Hence, mass fluxes can be calculated from concentration measurements in precipitation (input) and in the rivers Rhine and Rhone at the border of Switzerland (output). To our knowledge, the presented field study covering a time period of 16 months is the first investigation that describes simultaneously the occurrence and the mass fluxes of MCA, DCA, TCA and TFA on a large regional scale.

\section{Experimental Section}

Materials. Reference haloacetic acid compounds and 2,2-dichloropropionic acid (2,2-DCPA) were purchased from Aldrich (Steinheim, Germany) $>98 \%$ and were used as received. The derivatization agent 1-(pentafluorophenyl) diazoethane was synthesized following the procedure described by Meese (26), filled in tight $0.8 \mathrm{~mL}$ glass vials under argon atmosphere and stored at $-80{ }^{\circ} \mathrm{C}$. All other chemicals and solvents were obtained from Fluka (Buchs, 
Switzerland) or Merck (Darmstadt, Germany) in the best available quality and used without further purification. The reactant gas methane was purchased from Carbagas (Zürich, Switzerland). Nanopure water was obtained from deionized water which was further purified with a Nanopure water purification device (NANOpure 4, Skan, Basel, Switzerland).

Sampling and Sample Preparation. The sampling sites and their characteristics are described in Table 1. Also, four swimming pools and five industrial waste waters were analyzed. Entire precipitation events and time resolved rain events were sampled $2 \mathrm{~m}$ above surface with polyethylene funnels of $0.05 \mathrm{~m}^{2}$ and a very big Teflon funnel of $5 \mathrm{~m}^{2}$, respectively. The rain samplers were cleaned with tap water, dried with unbleached paper cloth and covered with polyethylene foil until sampling. The samples were collected in borosilicate glass flasks. The Rhine water at Weil and the waste water effluents were taken with flow proportional samplers equipped with cooled sampling containers $\left(4{ }^{\circ} \mathrm{C}\right)$. Grab samples of river water, lake water and moor water were collected directly with $100 \mathrm{~mL}$ polyethylene flasks $0.5 \mathrm{~m}$ below surface. Immediately after collection, all samples were conserved with $0.06 \%(\mathrm{w} / \mathrm{v})$ of $\mathrm{NaN}_{3}$ and transported within less then 24 hours to the laboratory. Caution: $\mathrm{NaN}_{3}$ is highly toxic, contact with skin and mucous membranes must be avoided. Note that $\mathrm{NaN}_{3}$ did not have any influence on the HAAs measurements, in contrast to formaldehyde which caused irreproducible derivatization efficiencies. All samples were stored in $100 \mathrm{~mL}$ polyethylene flasks at $-20^{\circ} \mathrm{C}$ until analysis.

Precipitation and surface water samples from Norway, Russia (Siberia) and Vietnam were taken for comparative purposes. They were sampled in duplicate in $50 \mathrm{~mL}$ polyethylene flasks, preserved on-site with $\mathrm{NaN}_{3}$, and stored at $4{ }^{\circ} \mathrm{C}$. Sample contamination during transport was monitored by carrying HAA free samples of very old ground water (see Table 3) along the journey.

Sample preparation was carried out in a secluded building where no haloacetic acids were used. To avoid contamination by ambient air, the sample handling was carried out on a clean 
bench (Astecair 4000E, Skan, Basel, Switzerland). Haloacetic acids eventually present on the glassware surface were destroyed/removed by heating the equipment for at least 2 hours to $200{ }^{\circ} \mathrm{C}$ in an oven which was continuously purged with purified air (Lüdi, Zürich, Switzerland). All samples were extracted and analyzed in duplicates.

Analytical Procedure. Water samples consisting of $10 \mathrm{~mL}$ aliquots were added individually to a stoppered glass vial $(25 \mathrm{~mL})$ and spiked with $500 \mathrm{ng} / \mathrm{L}(10 \mu \mathrm{L}$ of a $500 \mu \mathrm{g} / \mathrm{L}$ methanolic solution) of internal standard 2,2-DCPA. The sample was shaken for $5 \mathrm{~s}$, acidified with 440 $\mu \mathrm{L}$ concentrated sulfuric acid (98\%), and cooled in ice water to $10{ }^{\circ} \mathrm{C}$. Then, $2.0 \mathrm{~g}$ of $\mathrm{NaCl}$ and $2.0 \mathrm{~mL}$ methyl-t-butyl ether (MTBE) were added. The analytes were extracted into the MTBE phase by vortexing the vial for exactly 3 minutes. The samples were again cooled in ice water until phase separation. The extracted haloacetic acids were derivatized according to Frank et al. (27). Briefly, $10 \mu \mathrm{L}$ of the derivatization agent 1-(pentafluorophenyl) diazoethane $(1 \% \mathrm{v} / \mathrm{v}$ in MTBE) was placed in a GC vial followed by the immediate addition of $200 \mu \mathrm{L}$ of the MTBE sample extract. The GC vials were then kept for 8 hours at room temperature in the dark. The haloacetic acid 1-(pentafluorophenyl)-ethyl esters were analyzed by GC/MS (see below) within 24 hours or stored at $-20^{\circ} \mathrm{C}$ if a delay of more than 1 day occurred.

A Fisons gas chromatograph (GC 8000) and a mass spectrometer system (MD 800) equipped with an autosampler (AS 800) was used for analysis. The GC was equipped with a deactivated fused silica pre-column $(1 \mathrm{~m} \times 0.53 \mathrm{~mm})$ and a $15 \mathrm{~m} \times 0.25 \mathrm{~mm}$ DB-5ms capillary column (J\&W Scientific, Folsom, CA). The carrier gas helium was set to a constant inlet pressure of $50 \mathrm{kPa} .2 \mu \mathrm{L}$ of the derivatized sample extract were injected on-column at 55 ${ }^{\circ} \mathrm{C}$. After $1 \mathrm{~min}$, the temperature was raised with $10{ }^{\circ} \mathrm{C} / \mathrm{min}$ to $200^{\circ} \mathrm{C}$, and with $30{ }^{\circ} \mathrm{C} / \mathrm{min}$ to $230{ }^{\circ} \mathrm{C}(2 \mathrm{~min})$. The $\mathrm{GC} / \mathrm{MS}$ interface temperature was set to $250{ }^{\circ} \mathrm{C}$. The MS source was operated at $200{ }^{\circ} \mathrm{C}$ in the negative chemical ionization mode (NCI) with the reactant gas methane at a partial source pressure of $4 \times 10^{-5} \mathrm{~Pa}$ and an electron energy of $70 \mathrm{eV}$. The haloacetic acid esters dissociated into the haloacetate ions and 1-(pentafluorophenyl) ethane. The following mass traces (m/z) were monitored: 113 for TFA, 93 and 95 for MCA, 127 and 
129 for DCA, 141 and 143 for 2,2-DCPA, and 161 and 163 for TCA. The MS detector voltage was set to $400 \mathrm{~V}$.

Quality Assurance: Calibration, Relative Recoveries, and Detection Limits. For calibration and recovery studies, Nanopure water and natural waters were spiked with haloacetic acids dissolved in methanol. Because HAAs were occasionally detected in Nanopure water (15-90 ng/L), calibration curves were obtained by extracting and analyzing very old ground water (see Table 3) spiked with internal standard 2,2-DCPA and varying haloacetic acid concentrations. For each calibration, a blank value was calculated and subtracted from the sample measurements. The calibrations were linear in the range of 0 $2000 \mathrm{ng} / \mathrm{L}$ (TFA, TCA) and 0-5000 ng/L (MCA, DCA) with coefficient of determination in the range of $r^{2} \geq 0.991$ and $r^{2} \geq 0.996$. Relative recoveries determined in Nanopure water, river water and rain water, and the limits of detection (LOD) and method detection limits (MDL) are summarized in Table 2. Changing sensitivity and precision of the analysis caused different MDLs for different sample sequences. Therefore, MDLs for every sequence were determined. The average relative standard deviation (RSD) calculated from all single sample $\operatorname{RSD}(\mathrm{n}=1040)$ was $8.0 \%$ (ranging from $0.3 \%$ to $30 \%$ ).

Contamination and Blank Values. Despite the tremendous precautions taken, contamination during sample preparation could not be completely avoided. Detailed investigations revealed that haloacetic acids were present in ambient air, in sulfuric acid and in MTBE. Undistilled MTBE used as received from the manufacturer was less contaminated than freshly distilled MTBE, which indicates contamination during the reflux procedure. Consequently, undistilled MTBE from a new bottle was used for each series of analysis.

Furthermore, drifting partial pressure of the reactant gas in the MS source caused unstable responses of the haloacetic acid ions. The drift of generally increasing reactant gas pressure yielded lower haloacetic acid responses during a set of runs. Better stability was obtained when the reactant gas valve was adjusted 24 hours before analysis. During analysis a standard 
and a blank were measured after every 10th sample to monitor the drift. The additionally obtained calibration points were used for linear sample to sample interpolation of the calibration curves. With this practice, consistent measurements were obtained for sequences of more than 100 samples.

\section{Results and Discussion}

Overview of Haloacetic Acid Concentrations in Natural Waters. The data presented in Table 3 summarize the result of more than 1000 HAA concentration measurements. For the interested reader, the full database is available as Supplementary Information on the ES\&T Web site. The individual haloacetic acid concentrations measured in natural waters varied between a few nanograms and several thousand nanograms per liter. Only in a 15'000 year old ground water the HAA concentrations were below the method detection limits $(<11$ $\mathrm{ng} / \mathrm{L})$. In general, the concentrations observed in precipitation were significantly higher than those detected in surface waters (i.e., mountain lakes, midland lakes, rivers and moor water). These results confirm that the atmosphere is an important source of haloacetic acids and that precipitation is most likely the major transfer mechanism to the biosphere. In non-arid regions, dry deposition can be considered to be of minor importance, since the occurrence and transport of HAAs are primarily associated with liquid phases (28).

Haloacetic Acids in Precipitation. Figure 2 shows that despite the very different geographic characteristics of the precipitation sampling sites, and, despite the broad concentration range in single precipitation samples, the average HAA concentrations and their range in rain and snow did not differ by more than a factor of $2-3$. For example, the sampling site on the Jungfraujoch (3580 $\mathrm{m}$ above sea level; see Figure 1, abbreviation (f)) represents a remote alpine location that mainly received precipitation from both the Earth boundary layer (orographic lift) as well as the free troposphere. In contrast, the sampling site in Dübendorf (see Figure 1, abbreviation (a)) on the Swiss Midland (400-700 $\mathrm{m}$ above sea level) is a highly populated suburb of the city Zürich and receives precipitation which always scavenged the 
Earth's boundary layer (ca. 300-1000 m thick). Despite these differences, the measured average concentrations at the two sites were very similar and not statistically different from all other sites, including the site located at the southern side of the Alps (Locarno, see Figure 1, abbreviation (b)). Note that the rain events occurring in the southern part of Switzerland are primarily due to air masses coming from the south-southwest. No seasonal pattern of HAA concentrations in precipitation was observed during the 16 month study period.

As shown in Table 4, the average HAA concentrations in small precipitation events of $\leq 3 \mathrm{~mm}$ were about a factor 2 higher than in larger events of $>3 \mathrm{~mm}$. This can be explained by the washout dynamic of the HAAs, which is illustrated in Figure 3. This data was obtained with an ultra large funnel of $5 \mathrm{~m}^{2}$ area, allowing high resolution sampling of rain events. As can be seen, the initial concentrations measured in the first $0.05 \mathrm{~mm}(50 \mu \mathrm{m})$ precipitation of MCA, DCA, TCA and TFA decreased rapidly from 4730, 6270, 1090 and $980 \mathrm{ng} / \mathrm{L}$ to 10 -times lower concentrations during the first $2.4 \mathrm{~mm}$ precipitation which is consistent with their low pKa values and their small dimensionless Henry's law constants (28-30). During this rain event, higher concentrations at $3.6 \mathrm{~mm}$ precipitation were due to fresh air masses from southern direction (change of wind direction). Note that rapid washout with the first few millimeters of rain, also called "first-flush" effect, was further observed for pesticides analyzed in the same rain event $(31,32)$.

These findings illustrate that a significant number of rain samples must be considered in order to obtain average concentrations that can be used for mass flux calculations. Nevertheless, the similar average HAA concentrations and mass fluxes during the 16 months study period found at very different geographic and topographic locations suggest that HAAs in precipitation are derived from rather long lived and well mixed precursor(s) in the atmosphere. This hypothesis is supported by the investigations of Jordan et al. (8) and Wujcik et al. (7), which found similar HAA concentrations in rainwater in Germany and California (U.S.A.). 
Montzka et al. (33) observed that atmospheric HFC-134a, the major precursor of TFA, increased globally from early 1994 to mid-1995 with exponential growth at 100\% per year. When considering TFA, it is noteworthy that between 1996 and 1997, the measured average TFA concentrations in precipitation water were somewhat higher $[130 \mathrm{ng} / \mathrm{L}(\mathrm{n}=49)$ versus $200 \mathrm{ng} / \mathrm{L}(\mathrm{n}=24) ; \mathrm{t}$-test: $\mathrm{t}=1.20, \mathrm{p}=0.23]$. Further in 1995, an average TFA rain concentration of $100 \mathrm{ng} / \mathrm{L}(\mathrm{n}=34)$ was measured in Bayreuth/Germany by Frank and coworkers (4). Assuming similar TFA concentrations in rain in Switzerland and in Bayreuth (420 km northeast of central Switzerland), one might speculate that the higher average TFA concentration in rain in 1997 as compared to 1995 and 1996 reflects the increasing use/release of TFA precursors, i.e., HFC and HCFCs. However, future measurements are needed to establish a long-term trend of TFA concentrations in precipitation.

Midland Lakes, Rivers and Waste Water Effluents. The concentrations of MCA and DCA in surface waters (average of rivers and lakes) were significantly lower (15-20 times) than in precipitation, while TCA and TFA decreased only by factors 2.3 and 1.6, respectively (see Table 3 and Figure 4). Further, when moving from precipitation to surface waters (i.e. rivers), the TFA/CAA ratios increased as follows: TFA/MCA from 0.08 to 0.81 , TFA/DCA from 0.15 to 1.6 , and TFA/TCA from 0.63 to 0.76 . The TCA concentrations in the different rivers correlated well with the chloride concentrations (see Figure 5), indicating that waste water effluents are an important source of TCA in surface waters. Therefore, TCA originating from communal waste water effluents (average $2.4 \mu \mathrm{g} / \mathrm{L}$ ) may lead to an increase of the TCA concentration along rivers, i.e., Rhine and Rhone (see Figure 4; Rhine 1-3; Rhone 1-2). Note that no final disinfection is applied in waste water treatment in Switzerland. Therefore, the most probable TCA sources are processes involving active chlorine reacting with organic material (2), e.g., in cleaning agents, swimming pool waters, etc (see Table 3). The high TCA concentration in the river Aare at Brugg is caused by pulp mill factory effluents which was already identified as a point source in an earlier study (see Table 3 and ref. (2)). 
Grab samples from a chemical industry waste water treatment plant contained $207 \mu \mathrm{g} / \mathrm{L}$ TFA, and $544 \mu \mathrm{g} / \mathrm{L}$ TCA, indicating that such plants can also act as point sources of haloacetic acids. Consequently, communal and industrial waste water may be important point sources for TCA. For the other three compounds, however, only industrial waste waters showed significantly elevated concentrations.

Retention and/or Degradation of HAAs in the Aquatic Environment. The significantly lower CAA levels found in surface waters compared to levels present in precipitation (see Table 3) suggests some biological or chemical degradation of these compounds. Even in cold mountain lakes, the concentrations of the CAAs were much lower than in precipitation. Yet, a significantly higher TFA concentration (360 ng/L) as compared to precipitation water was measured in the exclusively meteorwater receiving mountain lake Tambo 2 which has no outflow. In contrast, only $100 \mathrm{ng} / \mathrm{L}$ TFA were found in the glacier lake Tambo 1 at $60 \mathrm{~m}$ distance to lake Tambo 2 (see Figure 1 and Table 1). This finding supports the postulated (12) accumulation of TFA in evaporative aqueous systems with limited degradation and seepage. In contrast to TFA, no accumulation of CAAs was observed in lake Tambo 2, indicating degradation of these chloro compounds.

Additional information on the persistence of the HAAs in natural waters were obtained from measurements of these compounds during river water - ground water infiltration at a well defined field site which is described in detail elsewhere $(34,35)$. Over the investigated infiltration distance of $26 \mathrm{~m}$ (residence time 8 days), a conservative behavior was observed for TFA. At the same time, the CAAs decreased to concentrations below the detection limit. These measurements indicate that TFA has a great potential to contaminate ground waters.

Haloacetic Acid Mass Fluxes over Switzerland. The estimated HAAs mass balances for Switzerland shown in Figure 6 are based on the measured average concentrations in precipitation, waste water (see Table 3), and river water (Rhine 3 and Rhone 2; see Table 1, Figure 1, and Figure 4). The annual mass fluxes (estimated error $\pm 25 \%$ ) were calculated using 
these average HAA concentrations and the hydrological data presented in Table 5. The calculations clearly show that precipitation is the dominant source for haloacetic acids (MCA: $2670 \mathrm{~g} \mathrm{~km}^{-2}$ year ${ }^{-1}$; DCA: $1530 \mathrm{~g} \mathrm{~km}^{-2}$ year $^{-1}$; TCA: $360 \mathrm{~g} \mathrm{~km}^{-2}$ year $^{-1}$; TFA: $230 \mathrm{~g} \mathrm{~km}^{-2}$ year'

$\left.{ }^{1}\right)$ and that communal and industrial waste waters are only important for TCA $(27 \%$, see Figure 6). The respective apparent disappearance of MCA, DCA and TCA of $97 \%, 97 \%$ and $77 \%$, reflects losses as a result of degradation and, possibly, accumulation in the soil and ground water environment. The lower apparent elimination rate obtained for TCA $(77 \%)$ is due to the input by waste water treatment plants yielding higher concentrations in the rivers (see text above). Moreover, our measured value for TCA is in very good agreement with data obtained in a previous study in 1993 (78\% (2)). The mass balance for TFA suggests an apparent elimination of about $60 \%$ in the catchment area. Considering TFA's persistence in the environment, one may postulate, that this compound can accumulate particularly in the soil and ground water environment. More measurements, however, are necessary to confirm this hypothesis.

Comparison with Other Measurements in the Northern Hemisphere. Table 6 summarizes haloacetic acid concentrations measured in precipitation and seawater in Norway and Vietnam and in precipitation and surface waters in Siberia (tributaries to lake Baikal and lake Baikal). The similar concentration range in precipitation in Switzerland, Norway, Siberia, and Vietnam supports the hypothesis that the precursors and/or the haloacetic acids are widely distributed in the atmosphere of the Northern Hemisphere. Further, despite the limited number of samples analyzed from other places than Switzerland, this comparison demonstrates that the results of this study are not limited to the region of Switzerland and that similar HAA concentrations can be expected elsewhere in the Northern Hemisphere. Unfortunately no similar data sets are presently available for comparison to the situation in the Southern Hemisphere.

Risk Assessment for the Aquatic Environment. Table 7 summarizes the parameters used for the risk assessment which is based on our measured environmental concentrations and 
toxicity data for MCA and TCA in aquatic ecosystems. The highest measured CAA concentrations in the lakes and rivers of the Swiss Midland are in the same order of magnitude as the calculated PNEC values (predicted no-effect concentration). Only at some sites the measured concentration was higher than the PNEC, e.g. MCA in moor water, and TCA in the river Glatt. This shows that organisms exposed to CAA point sources can be chronically affected.

Because of the strict regulations concerning the use of chlorinated volatile compounds, the abundance of CAAs in precipitation should further decrease in the near future. In contrast, due to the continuing replacement of CFCs with HFCs and HCFCs, and due to its persistence, TFA concentrations will increase in precipitation and, as discussed above, may therefore accumulate in certain natural compartments. Recently published TFA toxicities (11) and a TFA risk assessment study (13) suggest however, that TFA levels of up to $100 \mu \mathrm{g} / \mathrm{L}$ should not be harmful to aquatic ecosystems. Nevertheless, particularly with respect to the terrestrial environment, and with respect to ground water contamination, future trends in TFA concentrations in the environment should be monitored.

\section{Acknowledgements}

This work was partially founded by the Swiss Federal Office for Environment, Forest and Landscape (BUWAL). We are most thankful to G. Karlaganis, E. Müller, U. Stämpfli, and A. Weber (all BUWAL), St. Reimann (EMPA) and K. Grob (Food Control Authority of Zürich) for fruitful discussions. R. Hischier, P. Maurer, are acknowledged for their participation during their diploma thesis. We are grateful to H. Frank and A. Jordan (University of Bayreuth) for the introduction into HAA measurements. We would like to express many special thanks to the persons who have mindfully sampled water from remote sites, namely, U. Beyerle, R. Kipfer, O. Kocsis, B. Müller, M. Schurter, M. Sturm. (all EAWAG) and K. Mez (University of Zürich). Further, we are indebted to the staff of the Swiss Meteorological Agency for rain water sampling, to H. Debrunner (University of Berne) for giving access to 
the Jungfraujoch research station, S. Graf and M. Zehringer for organizing the transport of river water samples. Yu-Ping Chin, B. Escher, K. Fent, U. von Gunten, S. Reimann, and T. Schmidt, are acknowledged for reviewing the manuscript.

\section{Literature Cited}

(1) Frank, H.; Scholl, H.; Renschen, D.; Rether, B.; Laouedj, A.; Norokorpi, Y. Environ. Sci. \& Pollut. Res. 1994, 1, 4-14.

(2) Müller, S. R.; Zweifel, H. R.; Kinnison, D. J.; Jacobsen, J. A.; Meier, M. A.; Ulrich, M. M.; Schwarzenbach, R. P. Environ. Toxicol. Chem. 1996, 15, 1470-1478.

(3) Reimann, S.; Grob, K.; Frank, H. Environ. Sci. Technol. 1996, 30, 2340-2344.

(4) Frank, H.; Klein, A.; Renschen, D. Nature 1996, 382, 34.

(5) Zehavi, D.; Seiber, J. N. Anal. Chem. 1996, 68, 3450-3459.

(6) Juuti, S.; Hoekstra, E. J. Atmos. Environ. 1998, 32, 3059-3060.

(7) Wujcik, C. E.; Cahill, T. M.; Seiber, J. N. Environ. Sci. Technol. 1999, 33, 1747-1751.

(8) Jordan, A.; Frank, H. Environ. Sci. Technol. 1999, 33, 522-527.

(9) Scott, B. F.; Muir, D. C. G.; MacDonald, R.; Witter, A.; Fisk, A.; Spencer, C. Abstracts of Papers, 1st International Symposium on Atmospheric Reactive Substances, Bayreuth, Germany; University of Bayreuth: Bayreuth, Germany, 1999; 65.

(10) Hilton, J. L.; Ard, J. S.; Jansen, L. L.; Gentner, W. A. Weeds 1959, 7, 381-396.

(11) Berends, A. G.; Boutonnet, J. C.; de Rooij, C. G.; Thompson, R. S. Environ. Toxicol. Chem. 1999, 18, 1053-1059.

(12) Tromp, T. K.; Ko, M. K. W.; Rodriguez, J. M.; Sze, N. D. Nature 1995, 376, 327-330.

(13) Boutonnet, J. C.; Bingham, P.; Calamari, D.; de Rooij, C.; Franklin, J.; Kawano, T.; Libre, J. M.; McCulloch, A.; Malinverno, G.; Odom, J. M.; Rusch, G. M.; Smythe, K.; Sobolev, I.; Thompson, R.; Tiedje, J. M. Human And Ecological Risk Assessment 1999, $5,59-124$.

(14) Franklin, J. Toxicol. Environ. Chem. 1994, 46, 169-182.

(15) Naturally-Produced Organohalogens, Environment \& Chemistry; Grimvall, A.; de Leer, E. W. B., Eds.; Kluwer Academic Publishers: Dordrecht, Holland, 1995.

(16) Williams, D. T.; LeBel, G. L.; Benoit, F. M. Chemosphere 1997, 34, 299-316.

(17) Wallington, T. J.; Hurley, M. D.; Ball, J. C.; Kaiser, E. W. Environ. Sci. Technol. 1992, $26,1318-1324$.

(18) Franklin, J. Chemosphere 1993, 27, 1565-1601.

(19) Schwarzbach, S. E. Nature 1995, 376, 297-298.

(20) Richey, D. G.; Driscoll, C. T.; Likens, G. E. Environ. Sci. Technol. 1997, 31, 17231727. 
(21) Berger, T. W.; Tartowski, S. L.; Likens, G. E. Environ. Sci. Technol. 1997, 31, 19161921.

(22) Domsch, K. H. In Pestizide im Boden; VCH Verlag: Weinheim, Germany, 1992, pp 190-191.

(23) Boethling, T. W.; Alexander, M. Appl. Environ. Microbiol. 1979, 37, 1211-1216.

(24) Visscher, P. T.; Culberston, C. W.; Oremland, R. S. Nature 1994, 369, 729-731.

(25) Emptage, M.; Tabinowski, J.; Odom, J. M. Environ. Sci. Technol. 1997, 31, 732-734.

(26) Meese, C. O. Liebigs Ann. Chemie 1985, 1711-1714.

(27) Frank, H.; Renschen, D.; Klein, A.; Scholl, H. J. High Resol. Chromatogr. 1995, 18, $83-88$.

(28) Bowden, D. J.; Clegg, S. L.; Brimblecombe, P. J. Atmos. Chem. 1998, 29, 85-107.

(29) Bowden, D. J.; Clegg, S. L.; Brimblecombe, P. Chemosphere 1996, 32, 405-420.

(30) Bowden, D. J.; Clegg, S. L.; Brimblecombe, P. Water Air \& Soil Pollut. 1998, 101, 197-215.

(31) Bucheli, T. D.; Muller, S. R.; Heberle, S.; Schwarzenbach, R. P. Environ. Sci. Technol. 1998, 32, 3457-3464.

(32) Bucheli, T. D.; Muller, S. R.; Reichmuth, P.; Haderlein, S. B.; Schwarzenbach, R. P. Anal. Chem. 1999, 71, 2171-2178.

(33) Montzka, S. A.; Myers, R. C.; Butler, J. H.; Elkins, J. W.; Lock, L. T.; Clarke, A. D.; Goldstein, A. H. Geophys. Res. Lett. 1996, 23, 169-172.

(34) Schwarzenbach, R. P.; Giger, W.; Hoehn, E.; Schneider, J. K. Environ. Sci \& Technol. 1983, 17, 472-479.

(35) Hoehn, E.; von Gunten, H. R. Water Recources Res. 1989, 25, 1795-1803.

(36) Keith, L. H. Environmental Sampling and Analysis: A Practical Guide; Lewis: Chelsea, MI, 1991.

(37) Beyerle, U.; Purtschert, R.; AeschbachHertig, W.; Imboden, D. M.; Loosli, H. H.; Wieler, R.; Kipfer, R. Science 1998, 282, 731-734.

(38) Jakob, A.; Zobrist, J.; Davis, J. S.; Liechti, P.; Sigg, L. Gas Wasser Abwasser 1994, 74, 171-186 (in German).

(39) Report of the OECD Workshop on the Extrapolation of Laboratory Aquatic Toxicity Data to the Real Environment; Organization for Economic Cooperation and Development. Environment Directorate; Paris, France, 1992; OECD Environment Monographs No. 59. 


\section{Figure Captions}

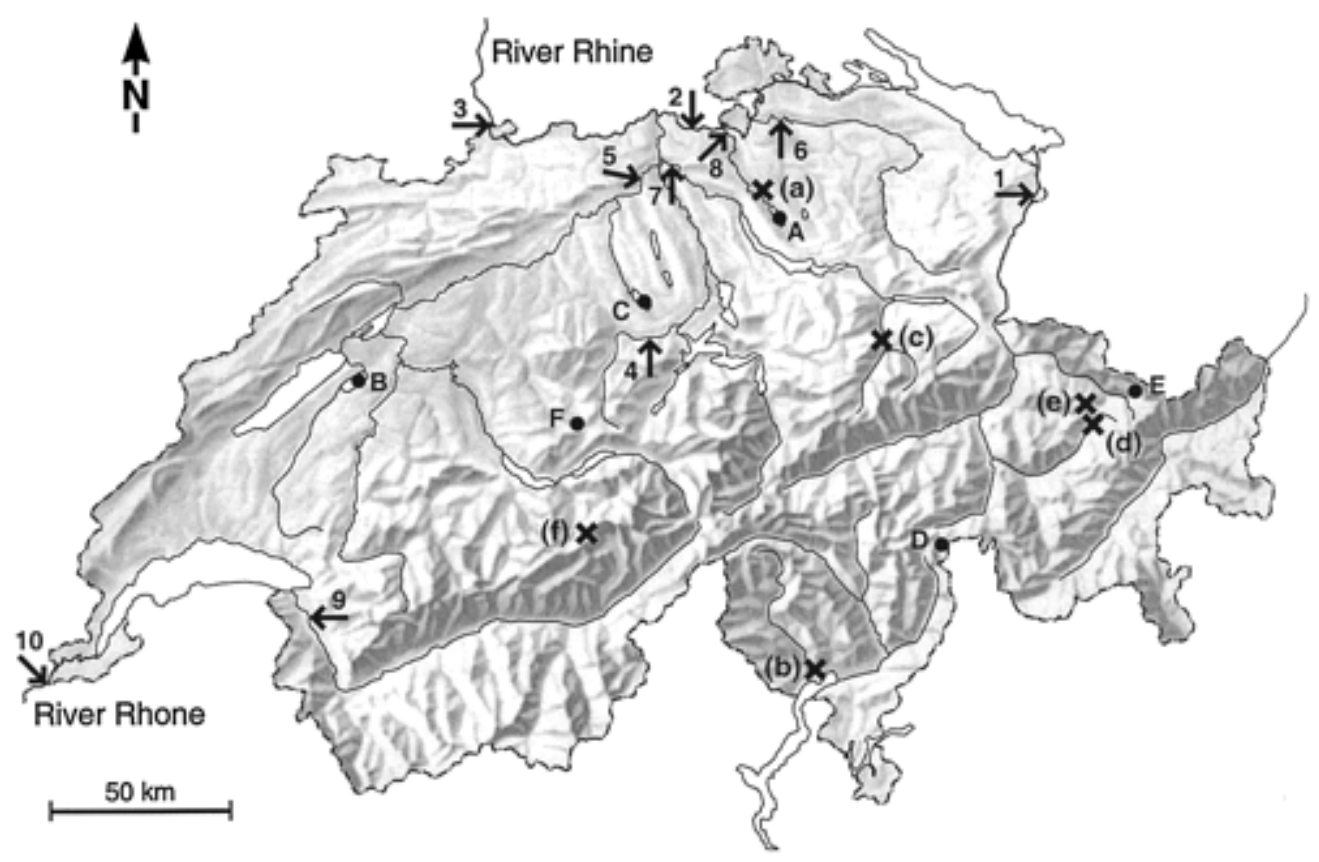

Figure 1. Map of Switzerland. Indicated are the sampling sites for precipitation ( $\times$ ), river water $(\rightarrow)$, and lake water $(\cdot)$. The sampling sites are characterized in Table 1. 

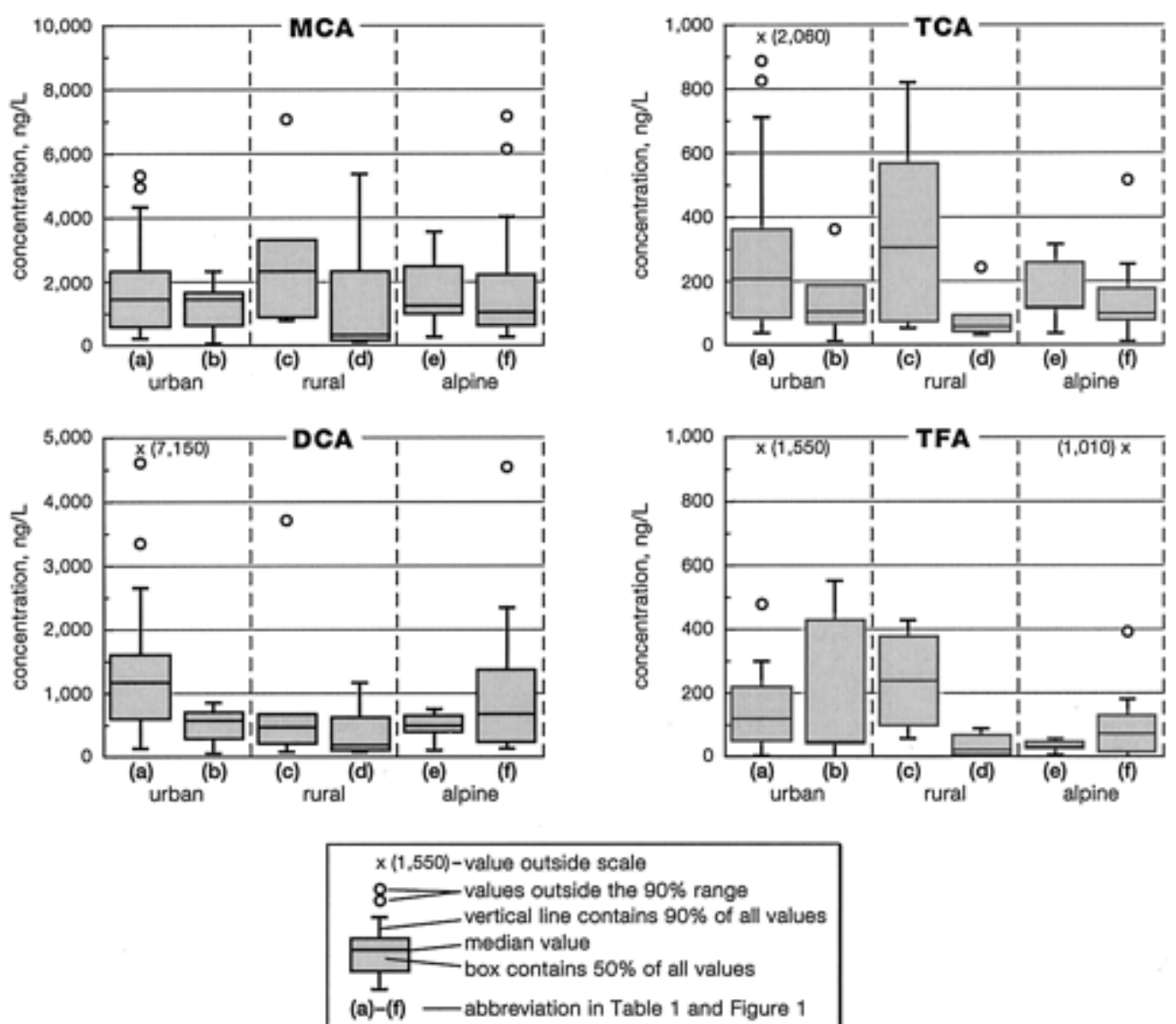

Figure 2. Box plots of the precipitation concentrations measured in entire precipitation events at different sampling sites. The locations are marked in Figure 1 and described in Table 1. They represent three categories of anthropogenic influence: Urban area, rural area, and alpine region. Note that the y-axes show different concentration ranges. 


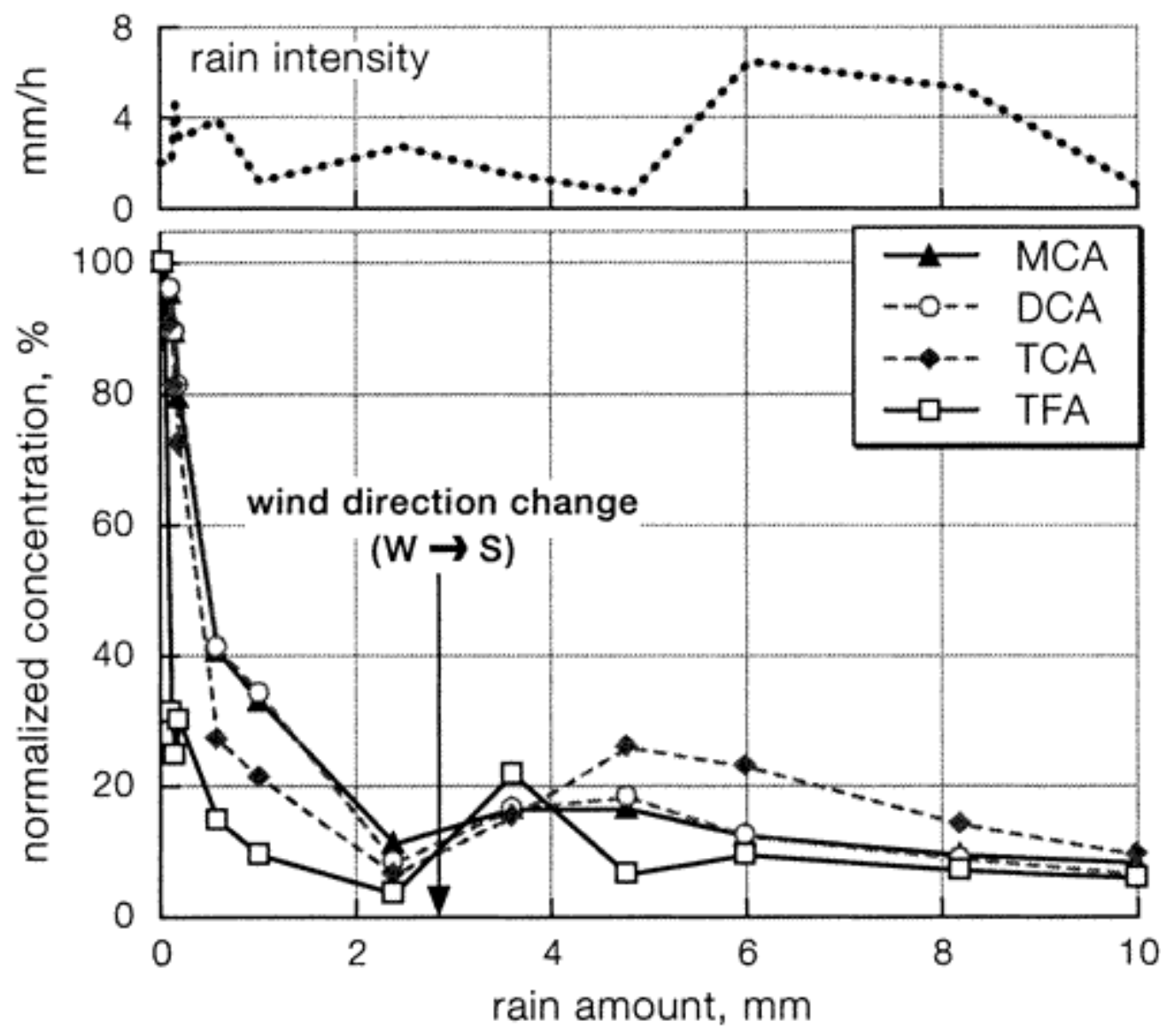

Figure 3. Time resolved washout behavior of chloroacetic acids and TFA during a rain event of $10.0 \mathrm{~mm}$ precipitation ( 5 hours). The values are normalized to the initial concentrations measured in the first $0.05 \mathrm{~mm}$ of precipitation (see text). The corresponding rain intensity is indicated by the line in the upper box. Following a dry period of 5 days the rain arrived from a westerly direction, and after $2.8 \mathrm{~mm}$ of precipitation, the wind direction changed from west to south. 

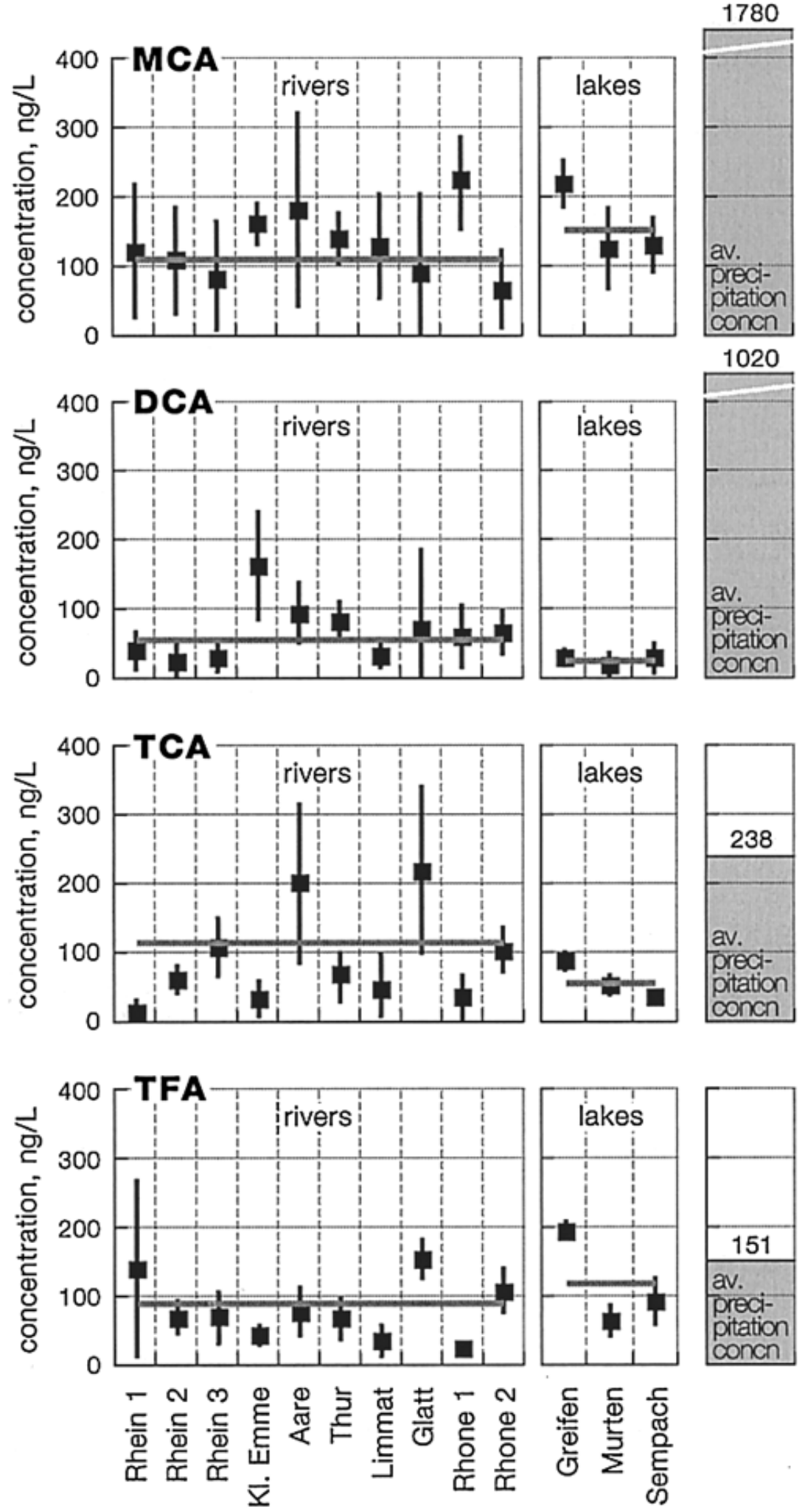

Figure 4. Average concentrations (black squares) and standard deviations (black vertical lines) of the chloroacetic acids and TFA in river waters and in lakes. The total average concentrations obtained for rivers and lakes are indicated by the gray horizontal bars. For comparison, the average precipitation concentration is shown in the right box. 


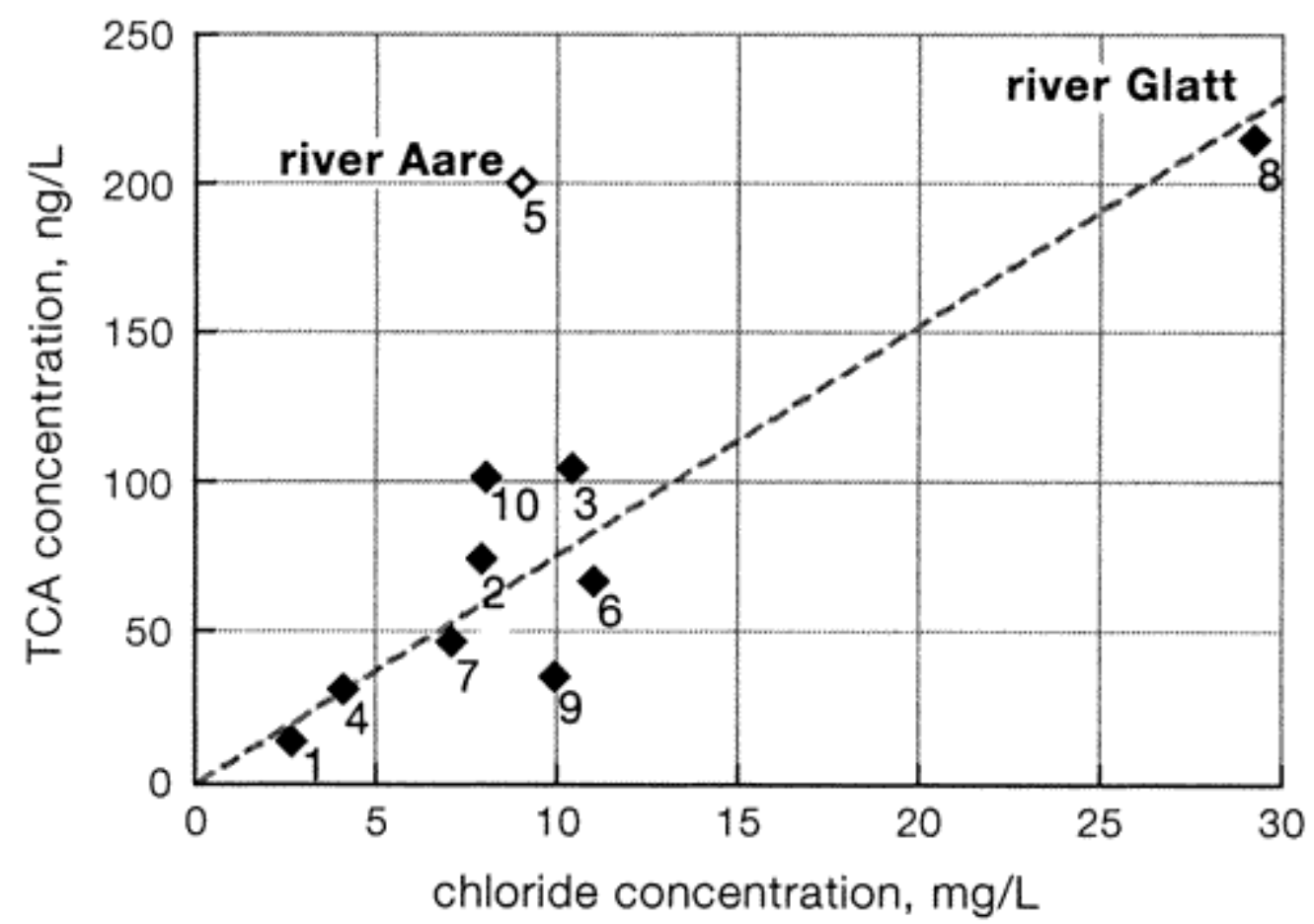

Figure 5. Correlation of average TCA concentrations with the average chloride concentrations in the rivers. Chloride which derives mainly from anthropogenic sources is an indicator for the waste water load in the rivers. The locations are marked in Figure 1 and described in Table 1. Discarding the value of river Aare, a coefficient of determination of $\mathrm{r}^{2}=0.933$ was calculated. The high TCA concentrations in river Aare are due to effluent from a pulp mill factory (lignin oxidation with chlorine) located upstream of the sampling site (see text and reference (2)). 


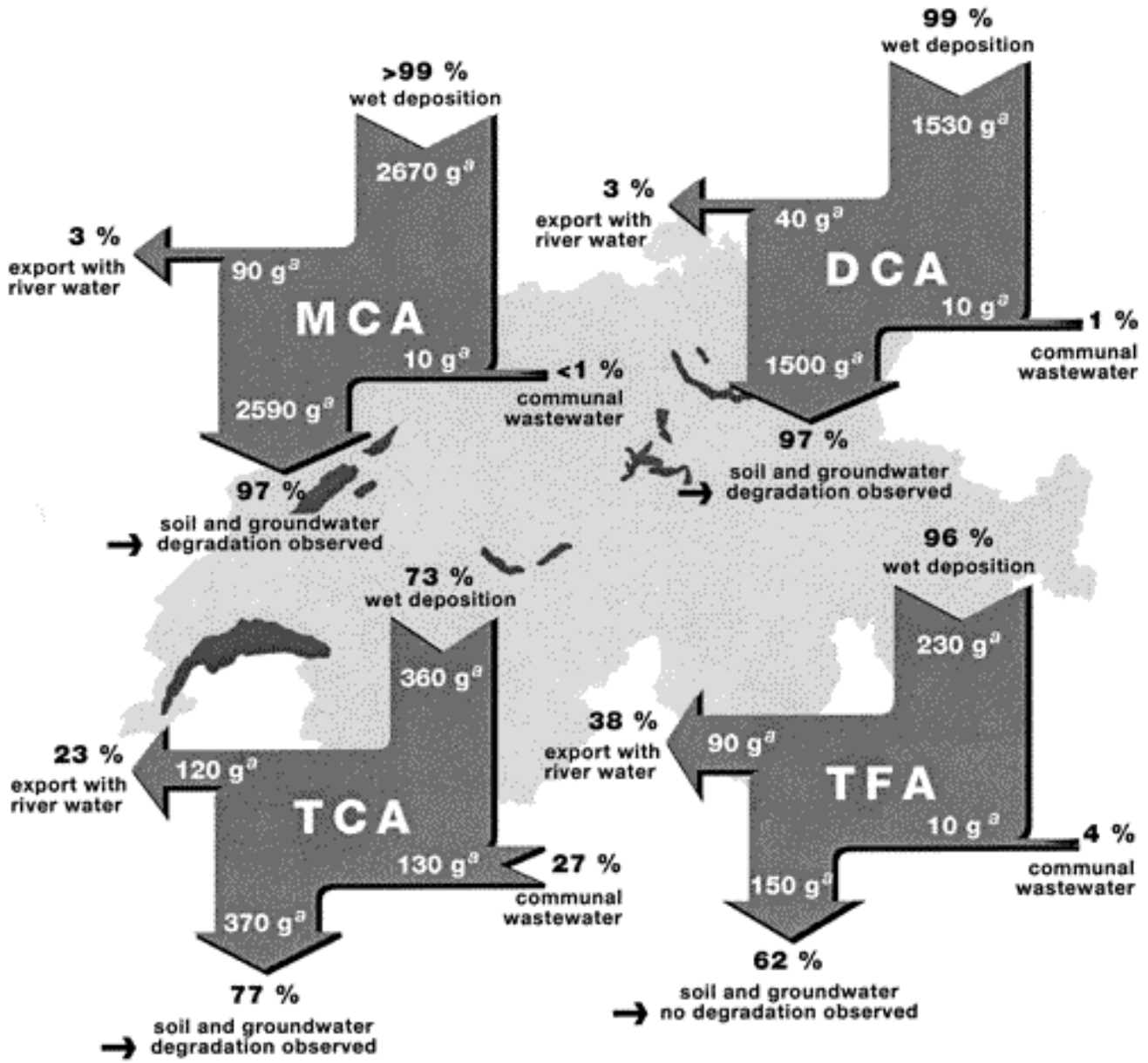

Figure 6. Annual mass fluxes of MCA, DCA, TCA, and TFA over the area of Switzerland. $a$ The values are given in $\mathrm{g} \mathrm{km}^{-2}$ year $^{-1}$ and in $\%$ of the total mass flux (estimated error $\pm 25 \%$ ). 


\begin{tabular}{|c|c|c|c|c|c|}
\hline $\mathrm{n}$ & $\begin{array}{l}\text { sampling site } \\
\text { (sampling period) }\end{array}$ & $\begin{array}{r}\text { abbr. } \\
\text { in Fig. } 1\end{array}$ & $\begin{array}{r}\text { ltitude } \\
(\mathrm{m})\end{array}$ & $\begin{array}{r}\text { av. prec } \\
(\mathrm{m}\end{array}$ & $\begin{array}{l}\text { itation } \\
\text { a/year) }\end{array}$ \\
\hline & rain and snow $(7 /$ & & & & \\
\hline 33 & Dübendorf & (a) & 430 & urban area, vicinity of Zürich & 1170 \\
\hline 8 & Locarno & (b) & 210 & urban area & 1930 \\
\hline 6 & Glarus & (c) & 520 & rural area & 1500 \\
\hline 6 & Davos & (d) & 1180 & rural area, below Weissfluhjoch (e) & 1150 \\
\hline 5 & Weissfluhjoch & (e) & 2690 & alpine mountain, above Davos (d) & 2840 \\
\hline & Jungfraujoch & (f) & 3580 & high alpine mountain, permanent snow & 4150 \\
\hline
\end{tabular}

rivers $(5 / 96-6 / 97)$

$\begin{array}{rlllll}4 & \text { Rhine } 1 & \text { at Diepoldsau } & 1 & 410 & \text { alpine catchment } \\ 8 & \text { Rhine 2 } & \text { at Rekingen } & 2 & 320 & \text { lake Konstanz in catchment } \\ 21 & \text { Rhine 3 } & \text { at Weil } & 3 & 240 & \text { lake Konstanz in catchment } \\ 4 & \text { Kl. Emme } & \text { at Littau } & 4 & 430 & \text { alpine catchment } \\ 5 & \text { Aare } & \text { at Brugg } & 5 & 330 & \text { several lakes in catchment } \\ 4 & \text { Thur } & \text { at Andelfingen } & 6 & 360 & \text { rural catchment } \\ 4 & \text { Limmat } & \text { at Gebenstorf } & 7 & 330 & \text { lake Zürich in catchment } \\ 4 & \text { Glatt } & \text { at Rheinsfelden } & 8 & 340 & \text { densely populated catchment } \\ 4 & \text { Rhone 1 } & \text { at Porte du Scex } & 9 & 380 & \text { alpine catchment } \\ 13 & \text { Rhone 2 } & \text { at Chancy } & 10 & 350 & \text { lake Geneva in catchment }\end{array}$

midland lakes $c(5 / 97-6 / 97)$

6 Greifensee

8 Murtensee

6 Sempachersee

mountain lakes $d(7 / 97)$

$$
\begin{array}{lrr}
\text { A } & 440 & \text { eutrophic lake, } 32 \text { m deep } \\
\text { B } & 450 & \text { eutrophic lake, } 46 \text { m deep } \\
\text { C } & 500 & \text { eutrophic lake, } 87 \text { m deep }
\end{array}
$$

2 Tambo 1

2 Tambo 2

2 Jöri 1

2 Jöri 2

moor $(6 / 97)$

3 Steinmoos at Schangnau

D 2330 alpine glacier lake, $9 \mathrm{~m}$ deep

D 2360

E 2520

alpine meteor water lake, $1 \mathrm{~m}$

E 2560 alpine lake, $6 \mathrm{~m}$ deep

F 930 pristine moor, alpine

communal waste waters effluents $f(5 / 97-7 / 97)$

$\begin{array}{ll}3 & \text { Pfungen } \\ 3 & \text { Niederglatt } \\ 4 & \text { Uster } \\ 3 & \text { Winterthur } \\ 4 & \text { Zürich }\end{array}$

4 Zürich av. water discharge $\left(\mathrm{m}^{3 / \mathrm{s}}\right)$

$$
230
$$$$
440
$$$$
1069
$$

314

9

102

7

172

326

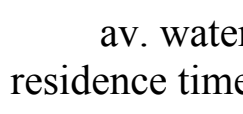

(years)

1.1

1.6

15.0 av. altitude of catchm.

(m)

1800

1260

1100

1050

1010

770

1130

498

2130

1580

surface

area

$\left(\mathrm{km}^{2}\right)$

8.5

22.8

14.4

$0.1-0.3^{e}$

0.01

$<0.01$

0.05

0.01

$0.1-0.4^{e}$ $0.05-0.1^{e}$

inhabitants $b$ in catchm. $\left(\mathrm{inh} / \mathrm{km}^{3}\right)$

660000

138000

19000

1600

4360

1380

6470

3110

6180

7140

8260

39970

(

in catchm.

$\left(\mathrm{inh} /\left(\mathrm{m}^{3} / \mathrm{s}\right)\right)$

0
0
0
0

0
industrial $g$ ratio (\%)

av. sludge age (d)

inhabitants in catchm.

10000

38000

65000

140000

415000 
$a$ Water discharge proportional number of inhabitants in catchment area. ${ }^{b}$ Lake volume proportional number of inhabitants in catchment area. ${ }^{c}$ Samples were taken with a Niskin bottle at various depths at the deepest point of the lake. ${ }^{d}$ Samples were taken from the shore. $e$ Water residence time is strongly dependent on weather conditions. $f$ No disinfecting agents are used in Switzerland for waste water treatment. $g$ Fraction of industrial waste water treated in the plant. ${ }^{h}$ Location not shown in Figure 1. 
Table 2. Recoveries in Nanopure Water and in Natural Waters, Relative Standard Deviations (RSD) and Detection Limits (LOD, MDL) of the Analytical Procedure

\begin{tabular}{|c|c|c|c|c|c|c|c|c|}
\hline \multirow[b]{3}{*}{ spike level } & \multirow{2}{*}{$\begin{array}{c}\text { Nanopure water }(n=9) \\
\text { recovery } \\
\%(\mathrm{RSD})\end{array}$} & \multicolumn{2}{|c|}{ river water $(n=4)$} & \multicolumn{2}{|c|}{ rain water $(n=4)$} & \multicolumn{3}{|c|}{ detection limits } \\
\hline & & $\begin{array}{c}\operatorname{concn}^{a} \\
\mathrm{ng} / \mathrm{L}(\mathrm{RSD})\end{array}$ & $\begin{array}{l}\text { recovery } \\
\% \text { (RSD) }\end{array}$ & $\begin{array}{c}\operatorname{concn}^{a} \\
\text { ng/L (RSD) }\end{array}$ & $\begin{array}{l}\text { recovery } \\
\% \text { (RSD) }\end{array}$ & $\begin{array}{c}\mathrm{LOD}^{b} \\
\mathrm{ng} / \mathrm{L}\end{array}$ & & $\begin{array}{l}\mathrm{L}^{c} \\
/ \mathrm{L}\end{array}$ \\
\hline & $100-430 \mathrm{ng} / \mathrm{L}$ & - & $200 \mathrm{ng} / \mathrm{L}$ & - & $200 \mathrm{ng} / \mathrm{L}$ & & av. & range \\
\hline $\mathrm{MCA}$ & $94(6)$ & $22(8)$ & $94(4)$ & 518 (2) & $97(3)$ & 2 & 21 & $6-59$ \\
\hline DCA & $103(7)$ & 119 (3) & $97(6)$ & $259(5)$ & $95(11)$ & 1 & 13 & $8-37$ \\
\hline TCA & $97(9)$ & $612(2)$ & $92(3)$ & $146(2)$ & $97(8)$ & 4 & 18 & $4-52$ \\
\hline TFA & $103(8)$ & 77 (2) & $96(10)$ & $99(7)$ & $103(6)$ & 0.3 & 11 & $3-43$ \\
\hline
\end{tabular}

${ }^{a}$ Concentration quantified in unspiked water. ${ }^{b}$ LOD calculated from signal to noise ratio $(3: 1) .{ }^{c}$ The MDL, defined as three times the standard deviation of low concentrations (36), was determined for every new set of samples. 
Table 3. Average HAA Concentrations ${ }^{a}$ Measured in Switzerland (1996-97)

\begin{tabular}{|c|c|c|c|c|c|c|c|c|c|}
\hline \multirow{2}{*}{ natural waters } & \multirow[b]{2}{*}{$\mathrm{n}$} & \multicolumn{2}{|c|}{$\begin{array}{c}\text { MCA } \\
\text { concentration }\end{array}$} & \multicolumn{2}{|c|}{$\begin{array}{c}\text { DCA } \\
\text { concentration }\end{array}$} & \multicolumn{2}{|c|}{$\begin{array}{c}\text { TCA } \\
\text { concentration }\end{array}$} & \multicolumn{2}{|c|}{$\begin{array}{c}\text { TFA } \\
\text { concentration }\end{array}$} \\
\hline & & $\begin{array}{c}\text { average } \\
\mathrm{ng} / \mathrm{L}\end{array}$ & $\begin{array}{l}\text { range } \\
\mathrm{ng} / \mathrm{L}\end{array}$ & $\begin{array}{c}\text { average } \\
\mathrm{ng} / \mathrm{L}\end{array}$ & $\begin{array}{l}\text { range } \\
\mathrm{ng} / \mathrm{L}\end{array}$ & $\begin{array}{c}\text { average } \\
\text { ng/L }\end{array}$ & $\begin{array}{l}\text { range } \\
\text { ng/L }\end{array}$ & $\begin{array}{c}\text { average } \\
\mathrm{ng} / \mathrm{L}\end{array}$ & $\begin{array}{l}\text { range } \\
\mathrm{ng} / \mathrm{L}\end{array}$ \\
\hline rain and snow & 73 & 1780 & $60-7170$ & 1020 & $32-7150$ & 238 & $<4-2060$ & 151 & $<3-1550$ \\
\hline rivers & 80 & 107 & $<6-320$ & 52 & $<11-240$ & 114 & $<4-700$ & 87 & $12-328$ \\
\hline midland lakes $b$ & 20 & 153 & $40-242$ & 27 & $<15-44$ & 58 & $33-96$ & 119 & $37-204$ \\
\hline mountain lakes ${ }^{c}$ & 8 & 215 & $71-417$ & 90 & $37-144$ & 46 & $<15-94$ & 141 & $46-360$ \\
\hline moor water & 3 & 389 & $247-476$ & 650 & $157-972$ & 15 & $<7-30$ & 107 & $59-175$ \\
\hline very old ground water $d$ & 3 & $<8$ & & $<11$ & & $<9$ & & $<5$ & \\
\hline other waters & & $\mathrm{ng} / \mathrm{L}$ & $\mathrm{ng} / \mathrm{L}$ & $\mathrm{ng} / \mathrm{L}$ & $\mathrm{ng} / \mathrm{L}$ & $n g / L$ & $\mathrm{ng} / \mathrm{L}$ & $\mathrm{ng} / \mathrm{L}$ & $\mathrm{ng} / \mathrm{L}$ \\
\hline drinking water $e$ & 6 & 75 & $20-211$ & 86 & $<6-217$ & 83 & $<20-225$ & 71 & $16-123$ \\
\hline & & $\mu \mathrm{g} / \mathrm{L}$ & $\mu \mathrm{g} / \mathrm{L}$ & $\mu \mathrm{g} / \mathrm{L}$ & $\mu \mathrm{g} / \mathrm{L}$ & $\mu \mathrm{g} / \mathrm{L}$ & $\mu \mathrm{g} / \mathrm{L}$ & $\mu \mathrm{g} / \mathrm{L}$ & $\mu \mathrm{g} / \mathrm{L}$ \\
\hline swimming pools $f$ & 4 & 46.5 & $11.0-117$ & 76.0 & $0.9-240$ & 44.9 & $17.1-94.7$ & 4.8 & $4.1-5.7$ \\
\hline communal waste water $f, g$ & 17 & 0.12 & $0.01-0.28$ & 0.20 & $<0.01-1.41$ & 2.4 & $0.13-31.3$ & 0.23 & $0.09-0.60$ \\
\hline industrial waste water $f, g$ & 5 & 14.0 & $0.9-63.4$ & 8.1 & $0.4-34.8$ & 122 & $1.0-544$ & 47.3 & $<0.1-206$ \\
\hline
\end{tabular}

${ }^{a}$ The full database is available as Supplementary Information on the ES\&T Web site. ${ }^{b}$ Eutrophic lakes, situated in the Swiss midlands (400-500 m above sea level). ${ }^{c}$ Glacier lakes, situated $>2300 \mathrm{~m}$ above sea level in the Swiss Alps. ${ }^{d}$ The average age of this ground water is $15^{\prime} 000 \pm 1$ ' 800 years (37). ${ }^{e}$ Drinking 
water derived from unchlorinated ground water. $f$ Since these concentrations are not relevant for the mass balance, the locations are and not shown in Figure 1. $g$ Effluents of waste water treatment plants. 
Table 4. Average HAAs Concentrations Calculated from Entire Precipitation Events being $\leq 3.0 \mathrm{~mm}$ and $>3.0 \mathrm{~mm}$

\begin{tabular}{|c|c|c|}
\hline MCA & DCA & TCA \\
\hline $\mathrm{ng} / \mathrm{L}$ & $\mathrm{ng} / \mathrm{L}$ & $n g / L$ \\
\hline
\end{tabular}

$\begin{array}{lllll}\text { precipitation amount } \leq 3.0 \mathrm{~mm} & 29 & 2410 & 1560 & 330\end{array}$

$\begin{array}{llllll}\text { precipitation amount }>3.0 \mathrm{~mm} & 48 & 1400 & 690 & 180 & 105\end{array}$ 
Table 5. Hydrological Data used for the Calculation of the Mass Fluxes of MCA, DCA, TCA and TFA in Switzerland

area of Switzerland

amount of total precipitation ${ }^{a}$

amount of communal waste water $b$

water outflow, river Rhein $a$

water outflow, river Rhone ${ }^{a}$

$\begin{aligned} 41.3 \times 10^{3} & \mathrm{~km}^{2} \\ 61.9 \times 10^{9} & \mathrm{~m}^{3} / \text { year } \\ 2.2 \times 10^{9} & \mathrm{~m}^{3} / \text { year } \\ 33.7 \times 10^{9} & \mathrm{~m}^{3} / \text { year } \\ 10.3 \times 10^{9} & \mathrm{~m}^{3} / \text { year }\end{aligned}$

$41.3 \times 10^{3} \quad \mathrm{~km}^{2}$

$\mathrm{m}^{3} /$ year

$33.7 \times 10^{9} \quad \mathrm{~m}^{3} /$ year

$10.3 \times 10^{9} \quad \mathrm{~m}^{3} /$ year

${ }^{a}$ Data from reference (38). ${ }^{b}$ Data from reference (2). 
Table 6. Occurrence of HAAs in Other Regions of the Northern Hemisphere ${ }^{a}$ and Comparison with the Average Concentrations Determined in Switzerland in 1996-1997

\begin{tabular}{|c|c|c|c|c|c|c|c|}
\hline & & ampling dates & $\mathrm{n}$ & $\begin{array}{c}\text { MCA } \\
\text { ng/L }\end{array}$ & $\begin{array}{c}\text { DCA } \\
\text { ng/L }\end{array}$ & $\begin{array}{c}\text { TCA } \\
\text { ng/L }\end{array}$ & $\begin{array}{l}\text { TFA } \\
\text { ng/L }\end{array}$ \\
\hline \multirow[t]{3}{*}{ rain and snow } & Baikal, Siberia & $6 / 96,12 / 96$ & 6 & $210-1650$ & $145-2060$ & $<4-113$ & $30-215$ \\
\hline & Hanoi, Vietnam & $8 / 96$ & 4 & $144-1930$ & $18-220$ & $21-64$ & $4-150$ \\
\hline & Switzerland, average & $5 / 96-7 / 97$ & 73 & 1780 & 1020 & 238 & 151 \\
\hline \multirow[t]{2}{*}{ rivers } & Baikal, Siberia & $6 / 96,7 / 97$ & 8 & $18-280$ & $<8-68$ & $<6-69$ & $19-115$ \\
\hline & Switzerland, average & $5 / 96-7 / 97$ & 80 & 107 & 52 & 114 & 87 \\
\hline \multirow[t]{3}{*}{ lakes } & Baikal, Siberia $b$ & $6 / 96$ & 6 & $<8-30$ & $<9-12$ & $<6$ & $12-35$ \\
\hline & Tornetrask, Norway & $7 / 96$ & 1 & 174 & 24 & 82 & 47 \\
\hline & Switzerland, average & $6 / 96-7 / 97$ & 20 & 153 & 27 & 58 & 119 \\
\hline \multirow[t]{2}{*}{ sea water } & Haiphong, Vietnam & $7 / 96$ & 2 & 43,122 & 13,23 & 16,49 & 53,66 \\
\hline & Lofotes, Norway & $7 / 96$ & 2 & 84,92 & 95,110 & 43,55 & 64,65 \\
\hline
\end{tabular}

$a$ The full database is available as Supplementary Information on the ES\&T Web site. ${ }^{b}$ Samples were taken from the epilimnion and the hypolimnion in the north, the middle, and the south basin of lake Baikal. 
Table 7. Data used for the Risk Assessment of MCA, and TCA

MCA

TCA

lowest reported toxicity

$10 \mu \mathrm{g} / \mathrm{L}^{a}$

$10-1000 \mu \mathrm{g} / \mathrm{L}^{b}$

tested organism

green algae crustaceans

green algae

mollusces crustaceans fish, insects

test parameter

EC10, EC50

EC50, EC100

LC50

no. of data

3

4

extrapolation factor according to $\mathrm{OECD} 1992^{c}$

100

100

predicted no effect concentration (PNEC)

$0.1 \mu \mathrm{g} / \mathrm{L}$

$0.1-10 \mu \mathrm{g} / \mathrm{L}$

highest measured concentration in surface water ${ }^{d}$

$0.48 \mu \mathrm{g} / \mathrm{L}$

$0.70 \mu \mathrm{g} / \mathrm{L}$

$a$ Data from reference (1). ${ }^{b}$ Data from reference (2). ${ }^{c}$ Data from reference (39). $d$ Concentrations measured in this study. 